Sanja Lazanin

\section{Slika Drugoga i pismo o Sebi: grof Josip Rabatta (1661. - 1731.) o Hrvatskoj i sebi}

Zagreb: Srednja Europa, 2014, 275 str.

DOI: 10.11567/met.31.2.7

Autorica se $\mathrm{u}$ ovoj knjizi nastavlja baviti temom kojoj je posvetila i dio dosadašnjih istraživanja. Radi se o izvještajima grofa Josipa Rabatte, visokoga časnika u habsburškoj službi Vojne krajine i zapovjednoga generala u Karlovcu. Ta je vrsta izvora kao tipski »suhoparan" i usputni proizvod službeničke aktivnosti, nerijetko opterećena brojnim epitetima, ponudila uvid u različite segmente života u razdoblju kasnoga baroka na rubnim prostorima hrvatskih zemalja kao prostoru prelamanja različitih imperijalnih interesa i pretenzija. $U$ fokusu podrobne analize u ovoj knjizi tako se našla djelatnost plemića Rabatte, koji je potekao iz Goričke grofovije, a posebno njegovo viđenje zemlje $u$ kojoj je svoju službu obavljao na prijelazu iz 17. u 18. stoljeće. Šire gledano, knjiga objedinjuje dugogodišnje propitivanje vojnokrajiške problematike, razvoja plemstva i društvenih struktura ranonovovjekovlja uopće. Odgovarajući na uvijek aktualno istraživačko pitanje kako su stranci kao Drugi vidjeli prostore, ali i stanovnike hrvatskih povijesnih zemalja, autorica ujedno preispituje mogućnosti interpretacije izabranih povijesnih izvora i metoda. Ujedno donosi malu studiju oblikovanja odnosa i stavova vidljivih kroz reflektiranje stereotipâ i oslikavanje Drugoga u povijesnoj perspektivi, ssto ovaj rad svrstava u red u novije vrijeme intrigantnih imagoloških studija, nastalih kako u hrvatskom tako i u europskom znanstvenom okružju.

Knjiga je $\mathrm{u}$ tematskome i metodološkom smislu podijeljena na tri veća poglavlja, a sadržaj je legitimiran znatnim brojem bilježaka (699). Nakon pregleda konvencija i kratica upotrijebljenih izvora strukturno je podijeljena na uvod, dva tematska poglavlja i zaključak. Uz to je opremljena popisom priloga, izvora i literature, kazalom osobnih imena, geografskim kazalom te bilješkom o autorici.

Nakon što je u uvodu detaljno obrazložila odabrane izvore i literaturu, u prvom poglavlju »Josip Rabatta o sebi« autorica definira teorijske pojmove kojima će se koristiti. Potom postupno gradi sliku o grofu Rabatti na temelju lapidarnih segmenata slike koju pruža izabrana povijesna građa. Pokazalo se da izvještaji i slični službeni spisi omogućuju geopolitičku kontekstualizaciju Rabattine pojave i djelovanja na imperijalnome višegraničju na kraju 17. i početkom 18. stoljeća, ali i znatno više od toga. Preispitivanje koliko jednom grofu staleško društvo uopće omogućuje iskazivanje privatnoga uz javno u službenim spisima, već na prvi pogled izuzetno je zahtjevan zadatak. Usprkos tome autorica je rekonstruirala odraz u kojem je u procesu »individualizacije« kroz slikanje Drugoga moguće prepoznati i vlastitu (Rabattinu) inscenaciju "Sebe«. Društvene veze tog plemića i vojnika bile su bitna pretpostavka za stjecanje položaja, ali i uspjeh u obnašanju službe u vrijeme katoličke obnove i zamaha habsburškoga dvorskog apsolutizma.

Tek nakon metodološkoga, prostornoga i vremenskoga kontekstualiziranja problema koji je $\mathrm{u}$ fokusu analize u idućem poglavlju, "Slika Hrvatske u Rabattinim opisima«, suočava- 
mo se s otkrivanjem konkretnih slika Hrvatske u Rabattinim tekstovima. Nižući fizičko-geografske prikaze stanja na višegraničju, postupno dobivamo priliku ući u svijet staleški ustrojenih društvenih slojeva, ali se i upoznajemo sa specifičnim problemima na koje Rabatta nailazi u svojoj službi. Njegovi opisi obuhvaćaju slike odnosa s izravno nadređenima i podređenima, i to ne samo unutar istog staleža. Potom opisuje podložne mu krajišnike u različitom statusu, ali i svećenstvo. Stratificiranje drugih, tj. njihovo prikazivanje na različitim razinama drugosti, Rabatta, kao predstavnik katoličkog plemstva, realizira pretežito primjenjujući kriterij staleške ili konfesionalne pripadnosti. Slike mu djelomično prerastaju u stereotipne generalizacije, temeljene na prvo generaliziranome, a potom i subjektivno reduciranome iskustvu, odnosno, kako to autorica kaže, na nizu »kognitivnih prečica« (str. 106). Opisima neizbježnih pratitelja velikog i »malog « rata, poput stalnih migracija lokalnog stanovništva ili pljačke i krijumčarenja, koje su središnje vlasti licemjerno tolerirale kao dodatni izvor prihoda krajišnika kad su kasnile njihove vojne plaće, ali ih istovremeno zbog takvih »dodatnih aktivnosti« i kritizirale, Rabatta oportuno suprotstavlja opise vlastitih nastojanja da uvede red. Takvim kontrapunktom uz oslikavanje Drugoga postupno stvara i sliku Sebe. Osim toga iz formalnih dokumenata između redaka izbijaju regionalni i etnički stereotipi usmjereni prema krajišnicima općenito, ali i zamjetne regionalne različitosti u reprezentiranju stanovnika određenih područja (Hrvatske, Primorske ili Like i Krbave). U sudaru krajiškoga plemića i vojnokrajiških časnika s tradicij- skim zajednicama nastaju i vrlo čvrsti kulturni stereotipi, premda se Rabatta njima koristio situacijski. Njihove refleksije možemo čitati $\mathrm{u}$ ambivalentnosti njegove percepcije krajiškoga društva, odnosno barbarstva s jedne strane (Vlasi i Hrvati) i civiliziranosti (vojni časnici, plemstvo, Crkva) s druge. Dakako da uz cijelu lepezu razlika u pristupu drugima Rabattini izvještaji dokumentiraju i složene nijanse unutrašnjoaustrijsko-hrvatskih odnosa, uvjetovanih interesima dinastije s jedne strane, hrvatskih staleža s druge te vojnih i komorskih vlasti negdje između.

Predstavljajući svoje istraživanje o stvaranju slike o Sebi i Drugome prije svega kroz interpretaciju izvještaja kao podatkovno skromnih, kićenih, a opet često šablonski sastavljanih povijesnih izvora, autorica je ponudila mnogo više od rasvjetljavanja slike jedne konkretne povijesne osobe s hrvatskoga pograničja na značajnoj upravnoj, vojnoj i društvenoj poziciji. Kritički je preispitala ograničenja izabranih izvora te je usprkos tim ogradama ponudila odgovor na dvojbu u kojoj je mjeri Josip Rabatta utjelovio tipičnog predstavnika habsburškoga srednjoeuropskog i k tome katoličkog plemstva u vojnokrajiškoj službi, a koliko je bio samosvojan. Rabattine slike o sebi i Drugima možemo promatrati u vječnoj opreci uvjetovanoj samom njihovom prirodom. $S$ jedne strane, te su slike nastale na temelju općih i uobičajenih predodžbi, stereotipâ i reprezentacija, odnosno generalnih karakterizacija (pa i etnokarakterizacija) i ujedno su odraz Rabattinih želja, nedostataka ili nesigurnosti, a s druge su strane temeljene na iskustvu i sposobnosti individualne prosudbe. Dijagnosticiranje takve složene struktu- 
re spomenutih slika Drugoga omogućilo je prethodno otkrivanje različitih slojeva slike o Sebi, koju je Josip Rabatta stvarao i odražavao kroz vlastite stavove i predodžbe. Upravo zbog toga knjiga približava postupke kojima se kroz oslikavanje Drugoga može proniknuti dublje i u viđenje samoga Sebe. Pritom je drugost razotkrivana u rasponu od slikanja njegovih austrijskih staleških kolega kao njemu bliskih, preko lokalnog stanovništva pa sve do samih Osmanlija kao neprijatelja na suprotnome kraju spektra.

Autorica je svjesno odabrala »malu temu«, jasno odredila fokus istraživanja te je sa zavidnom lakoćom balansirala upotrijebljenu arhivsku građu, čemu je sigurno pridonijelo i njezino pionirsko proučavanje (i poučavanje) njemačke paleografije. Uz konciznost izraza i strogo ograničavanje na manji broj otvorenih pitanja u knjizi je iskazana zrelost oblikovanja postavljene ideje na svega dvjestotinjak stranica teksta. Uspješno se potvrđuje da čak i u žanru izvještaja i drugih sličnih pisanih dokumenata možemo pratiti izravni sraz općega i individualnoga (ili obiteljskoga), odnosno javnoga i privatnoga u staleškom društvu. Ujedno je omogućeno bolje razumijevanje društvenog položaja ranonovovjekovnog pojedinca plemićkog podrijetla, ali i Drugoga, kojeg i onda i danas zastire koprena društvenih stereotipa. Time knjiga pridonosi rasvjetljavanju povijesti sociokulturnih odnosa Habsburške Monarhije u važnom razdoblju osvajanja starih hrvatskih i ugarskih posjeda od Osmanlija te oblikovanja i jačanja apsolutizma. Gotovo u maniri krokija skicira obzore vojnokrajiškog ustroja, demografskih i migracijskih kretanja, etnič- kih promjena te raznih drugih segmenata svakodnevnog života na granici. Glavne aktere razotkriva u rasponu od samog sebe preko časnika do običnoga krajišnika, u vječitoj opreci Mi i Oni, civilizirani i barbari. Premda su i same u svojoj prirodi podvojene, kao što je, uostalom, i odnos Rabatte prema Vojnoj krajini bio ambivalentan, ponuđene su slike Hrvatske $u$ cijeloj knjizi svjesno slikane isključivo iz gornjeg rakursa, iz perspektive civilizatora.

Pisana vrlo suvremeno i teorijski superiorno, knjiga na postavkama interdisciplinarnosti, nezaobilazne $u$ društvenim i humanističkim znanostima, predstavlja vrijedan prilog istraživanju mogućnosti sociokulturnih analiza ranomodernoga doba. Na temelju pretraživanja ključnih hrvatskih i europskih arhiva za tu vrstu građe, prostor i razdoblje, autorica se okoristila »nekonvencionalnim « čitanjem velikog broja postojećih dopisa i izvještaja, koji su u nekim drugim okolnostima desetljećima prije bili uobičajeni izvori za sasvim drugačije vrste istraživanja. Dobro je to imati na umu u situaciji kad se upravo takvoj vrsti »službenih« izvora više »vjeruje« nego primjerice putopisima, s obzirom na činjenicu da potonji ionako podrazumijevaju dozu preuveličavanja. Osim toga knjiga je i metodološki iskorak $u$ recentnom problematiziranju slike Drugoga, stereotipâ i sličnih imagoloških formi, tražeći njihove refleksije na neočekivanim mjestima.

\section{Dubravka Mlinarić}

Institut za migracije i narodnosti, Zagreb 